\title{
Behavioural and biological correlates of physical functioning in middle aged office workers: the UK Whitehall II study
}

\author{
Mai Stafford, Harry Hemingway, Stephen A Stansfeld, Eric Brunner, Michael Marmot
}

\begin{abstract}
Study objectives-(1) To identify behavioural and biological correlates of poor physical functioning and (2) to determine whether such associations are independent of disease.

Design-Potential correlates were obtained from questionnaires and screening visits at baseline and five year follow up. Physical functioning was measured at follow up using the 10 item scale from the short-form 36 health survey.

Setting-London offices at baseline.

Participants-10 308 civil servants (6895 men and 3413 women), with a median age (range) of 49 years (39-63) at follow up. Main results-Multiple logistic regression showed that cigarette smoking, physical activity, body mass index (BMI), triglycerides, fibrinogen, and insulin were independently associated with poor physical functioning for men. For women, physical activity, eating habits, body mass index, fibrinogen, and insulin were independently associated with poor physical functioning. For example, among men, current smokers who had smoked more than 20 pack years were 1.89 (95\% CI 1.35 to 2.67$)$ times as likely to have poor physical functioning as never smokers. Men with BMI of 30 $\mathrm{kg} / \mathrm{m}^{2}$ or more were 1.71 (95\% CI 1.13 to 2.59) times as likely to have poor physical functioning as those with $B M I<20 \mathrm{~kg} / \mathrm{m}^{2}$. The corresponding odds ratio for women was $2.66(95 \%$ CI 1.80 to 3.93$)$. With the exceptions of fibrinogen and insulin, associations remained on exclusion of subjects with physical disease.

Conclusions-Risk factors established for physical diseases are associated with poor physical functioning in a population of working age. These associations may be independent of current disease.

(F Epidemiol Community Health 1998;52:353-358)
\end{abstract}

There is growing policy and research interest in the assessment of health functioning outcomes. ${ }^{12}$ Such self perceived outcomes are associated with use of health services, ${ }^{3}$ sickness absence, ${ }^{4}$ and mortality. ${ }^{35-7}$ Physical functioning is the most studied functional outcome and measures mobility and the ability to carry out daily activities. Physical functioning therefore provides an integrated measure of the impact of the diseases that lead to these symptoms and may also assess the impact of diseases that are as yet undiagnosed or in their early stages. ${ }^{8}$
There may be additional cardiorespiratory fitness effects on physical functioning that are independent of disease.

Risk factors for diseases have been widely investigated but there has been considerably less interest in identifying risk factors for poor physical functioning, despite the increasing prevalence of physical disability. ${ }^{9}$ Most existing studies have examined relatively severe limitations in elderly and patient populations. ${ }^{3}{ }^{10-18}$ Whether these effects were independent of overt disease was considered in only one of these studies, ${ }^{10}$ where risk factors were found to be associated with physical functioning independently of cardiovascular disease.

The short-form 36 general health survey (SF36) is among the most widely used measure of health functioning, both in clinical trials and cross sectional health surveys. ${ }^{19-21}$ We used the 10 item scale from the SF-36 to measure physical functioning. Participants in the Whitehall II study were all in employment at baseline, considerably younger than those studied previously and therefore relatively high functioning. The objectives of the current investigation were: (1) to identify behavioural, biochemical, and physiological correlates of poor physical functioning and (2) to assess whether such associations are independent of disease.

\section{Methods}

STUDY POPULATION

All non-industrial civil servants aged 35-55 years working in the London offices of 20 departments were invited to participate in this study. At baseline, between 1985 and 1988, a total of 10308 subjects (73\% of those eligible, comprising 6895 men and 3413 women), were enrolled, completing a self administered health questionnaire and attending for screening. Subjects completed another questionnaire and attended for a second screening at follow up, between 1991 and 1993. The mean length of follow up was 5.3 years, with a range of 3.7 to 7.6 years. One hundred and thirty subjects died before the start of the second screening examination. Analyses are based on the 5763 (85\%) men and $2586(77 \%)$ women who completed the SF-36 at follow up. Full details of the screening examinations are reported elsewhere. ${ }^{22}{ }^{23}$

\section{DEFINITION OF VARIABLES}

Physical functioning was assessed using the SF- $36^{24-26}$ at follow up and scored with the MOS scoring system. ${ }^{27}$ This scale has high internal consistency (Cronbach's alpha = 0.86). Responses to the question "Does your health now limit you in these activities? If so, 
Table 1 Associations between health related behaviours, biochemical risk factors, and physical functioning, adjusted for age: Whitehall II study 1985-1993

\begin{tabular}{|c|c|c|c|c|}
\hline Potential correlate & $\begin{array}{l}\text { Baseline (B)/ } \\
\text { follow up }(F)\end{array}$ & Level & $\begin{array}{l}\text { Men Odds ratio } \\
(95 \% \text { CI })\end{array}$ & $\begin{array}{l}\text { Women Odds ratio } \\
\text { (95\% CI) }\end{array}$ \\
\hline $\begin{array}{l}\text { Health related behaviours } \\
\text { Cigarette smoking }\end{array}$ & B & $\begin{array}{l}\text { Never smoker } \\
\text { Ex smoker } \\
\text { Current smoker ( } \leqslant 20 \text { packyears) } \\
\text { Current smoker ( }>20 \text { packyears) }\end{array}$ & $\begin{array}{l}1.00 \\
1.35(1.17,1.57) \\
1.73(1.33,2.25) \\
2.45(1.95,3.08) \\
\star\end{array}$ & $\begin{array}{l}1.00 \\
0.94(0.75,1.17) \\
0.78(0.55,1.11) \\
1.14(0.86,1.50)\end{array}$ \\
\hline Alcohol intake & B & $\begin{array}{l}\text { Non-drinker } \\
\text { Moderate drinker ( } \leqslant 21 \text { units) } \\
\text { Heavy drinker ( }>21 \text { units) }\end{array}$ & $\begin{array}{l}0.83(0.48,1.41) \\
1.00 \\
1.25(1.05,1.48) \\
\star\end{array}$ & $\begin{array}{l}1.44(1.00,2.07) \\
1.00 \\
1.22(0.74,2.03)\end{array}$ \\
\hline Physical activity $^{a}$ & $\mathrm{~B}$ & $\begin{array}{l}\text { Vigorous } \\
\text { Moderate } \\
\text { None/mild }\end{array}$ & $\begin{array}{l}1.00 \\
1.65(1.38,1.98) \\
1.94(1.61,2.34) \\
\star \star \star\end{array}$ & $\begin{array}{l}1.00 \\
1.73(1.19,2.52) \\
2.46(1.70,3.55) \\
\star \star \star\end{array}$ \\
\hline Eating habits $\dagger$ & B & $\begin{array}{l}\text { Healthy diet } \\
\text { Average diet } \\
\text { Unhealthy diet }\end{array}$ & $\begin{array}{l}1.00 \\
1.16(0.96,1.40) \\
1.59(1.27,1.98) \\
\star \star \star\end{array}$ & $\begin{array}{l}1.00 \\
1.38(1.09,1.76) \\
2.03(1.50,2.75) \\
\star \star \star\end{array}$ \\
\hline $\mathrm{BMI}\left(\mathrm{kg} / \mathrm{m}^{2}\right)$ & $\mathrm{B}$ & $\begin{array}{l}<20 \\
20-24.9 \\
25-29.9 \\
\geqslant 30\end{array}$ & $\begin{array}{l}1.32(1.96,1.83) \\
1.00 \\
1.37(1.19,1.58) \\
2.66(2.01,3.52) \\
\star \star \star\end{array}$ & $\begin{array}{l}0.93(0.53,1.42) \\
1.00 \\
1.93(1.57,2.37) \\
3.36(2.52,4.47) \\
\star \star \star\end{array}$ \\
\hline $\begin{array}{l}\text { Biochemical variables } \\
\text { Blood cholesterol } \neq\end{array}$ & B & $\begin{array}{l}\text { Lower tertile } \\
\text { Middle tertile } \\
\text { Upper tertile }\end{array}$ & $\begin{array}{l}\star \star \star \\
1.00 \\
0.90(0.76,1.06) \\
1.26(1.08,1.48) \\
\star \star \star\end{array}$ & $\begin{array}{l}\star \star \star \\
1.00 \\
0.97(0.88,1.22) \\
1.03(0.81,1.30)\end{array}$ \\
\hline Triglycerides $\$ & $\mathrm{~F}$ & $\begin{array}{l}\text { Lower tertile } \\
\text { Middle tertile } \\
\text { Upper tertile }\end{array}$ & $\begin{array}{l}1.00 \\
1.39(1.16,1.66) \\
2.09(1.76,2.48) \\
\star \star \star\end{array}$ & $\begin{array}{l}1.00 \\
1.42(0.97,1.39) \\
2.12(1.66,2.70) \\
\star \star \star\end{array}$ \\
\hline Fibrinogen $\|$ & $\mathrm{F}$ & $\begin{array}{l}\text { Lower tertile } \\
\text { Middle tertile } \\
\text { Upper tertile }\end{array}$ & $\begin{array}{l}1.00 \\
1.16(0.97,1.39) \\
1.58(1.33,1.88) \\
\star \star \star\end{array}$ & $\begin{array}{l}1.00 \\
1.19(0.92,1.53) \\
1.73(1.36,2.21) \\
\star \star \star\end{array}$ \\
\hline Glucose tolerance & $\mathrm{F}$ & $\begin{array}{l}\text { Normal } \\
\text { Impaired } \\
\text { Diabetic }\end{array}$ & $\begin{array}{l}1.00 \\
0.98(0.76,1.25) \\
1.82(1.15,2.87) \\
\star\end{array}$ & $\begin{array}{l}1.00 \\
1.37(1.02,1.82) \\
1.46(0.77,2.76) \\
\star\end{array}$ \\
\hline Insulin\# & $\mathrm{F}$ & $\begin{array}{l}\text { Lower tertile } \\
\text { Middle tertile } \\
\text { Upper tertile }\end{array}$ & $\begin{array}{l}1.00 \\
1.13(0.92,1.38) \\
1.86(1.54,2.26)\end{array}$ & $\begin{array}{l}1.00 \\
1.62(1.22,2.16) \\
2.75(2.09,3.61)\end{array}$ \\
\hline Physiological variables & & & $\star \star \star \star \Delta$ & $\star \star \star \star-10$ \\
\hline Diastolic blood pressure $^{\mathrm{b}}$ & B & $\begin{array}{l}1 \text { (Lowest qunitile) } \\
2 \\
3 \\
4 \\
5 \text { (Highest quintile) }\end{array}$ & $\begin{array}{l}1.00 \\
0.83(0.67,1.04) \\
0.84(0.68,1.04) \\
1.08(0.88,1.33) \\
1.03(0.84,1.28)\end{array}$ & $\begin{array}{l}1.00 \\
0.99(0.74,1.34) \\
1.16(0.85,1.59) \\
1.14(0.84,1.55) \\
1.27(0.94,1.71) \\
\star\end{array}$ \\
\hline Heart rate (beats per minute) $+\dagger$ & $\mathrm{F}$ & $\begin{array}{l}<60 \\
60-69 \\
70-79 \\
\geqslant 80\end{array}$ & $\begin{array}{l}1.00 \\
1.41(1.20,1.65) \\
1.29(1.06,1.57) \\
1.42(1.10,1.83) \\
\star \star\end{array}$ & $\begin{array}{l}1.00 \\
0.99(0.78,1.26) \\
1.06(0.81,1.39) \\
1.33(0.94,1.87)\end{array}$ \\
\hline
\end{tabular}

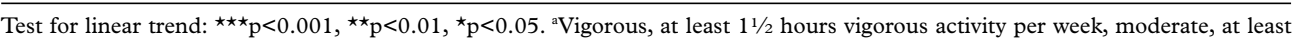
$1 \frac{1 / 2}{2}$ hours moderate activity per week, none/mild, less than $1 \frac{1 / 2}{2}$ hours moderate activity per week. $†$ Healthy diet, eat wholemeal, granary or wheatmeal bread, skimmed or semi-skimmed milk and fresh fruits or vegetables at least once daily, average diet, one or two of the above, unhealthy diet, none of the above. $\ddagger$ For men: lower $<5.5 \mathrm{mmol} / 1$, middle $5.5-6.3 \mathrm{mmol} / 1$, upper $\geqslant 6.4 \mathrm{mmol} / 1$. For women: lower $<5.3 \mathrm{mmol} / \mathrm{l}$, middle $5.3-6.2 \mathrm{mmol} / 1$, upper $\geqslant 6.3 \mathrm{mmol} / 1$. @ For men: lower $<1.03 \mathrm{mmol} / 1$, middle $1.03-1.65 \mathrm{mmol} / 1$, upper $\geqslant 1.65 \mathrm{mmol} / 1$. For women: lower $<0.83 \mathrm{mmol} / 1$, middle $0.83-1.23 \mathrm{mmol} / 1$, upper $\geqslant 1.23 \mathrm{mmol} / 1$. $\|$ For men: lower $<2.07 \mathrm{~g} / \mathrm{l}$, middle $2.07-2.46 \mathrm{~g} / 1$, upper $\geqslant 2.47 \mathrm{~g} / 1$. For women: lower $<2.27 \mathrm{~g} / 1$, middle $2.27-2.76 \mathrm{~g} / 1$, upper $\geqslant 2.77 \mathrm{~g} / 1$. $\uparrow / \mathrm{Normal}<7.8 \mathrm{mmol} / 1$, impaired $\geqslant 7.8 \mathrm{mmol} / 1$ and $<11.1 \mathrm{mg} / 1$, diabetic $\geqslant 11.1 \mathrm{mmol} / 1$. \#For men: lower $<3.9$ munits $/ 1$, middle $3.9-6.8 \mathrm{munits} / 1$, upper $\geqslant 6.9$ munits/1. For women: lower $<3.4$ munits/1, middle 3.4-6.4 munits/1, upper $\geqslant 6.5$ munits/l. ${ }^{b}$ For men: lowest $<73 \mathrm{~mm} \mathrm{Hg}, 2 \mathrm{nd} 73-78$ $\mathrm{mm} \mathrm{Hg}, 3 \mathrm{rd} 79-82 \mathrm{~mm} \mathrm{Hg}, 4$ th $83-87 \mathrm{~mm} \mathrm{Hg}$, highest $\geqslant 88 \mathrm{~mm} \mathrm{Hg}$. For women: lowest $<69 \mathrm{~mm} \mathrm{Hg}, 2 \mathrm{nd} 69-73 \mathrm{~mm} \mathrm{Hg}, 3 \mathrm{rd}$ $74-78 \mathrm{~mm} \mathrm{Hg}$, 4th $79-84$, highest $\geqslant 85 \mathrm{~mm} \mathrm{Hg}$. + Adjusted for use of $\beta$ blockers.

how much?" were sought for 10 items covering: (1) vigorous activities (for example, running, lifting heavy objects, strenuous sports), (2) moderate activities (for example, housework, playing golf), (3) lifting and carrying, (4)-(5) climbing stairs (several flights or one), (6) bending and kneeling, (7)-(9) walking (more than 1 mile, half a mile, 100 yards), and (10) bathing and dressing. Possible responses for each item were "A lot", "A little", and "Not at all", which scored 1, 2, and 3 respectively. These were summed over the 10 items and rescaled to create a physical functioning score ranging from 0 , indicating severe limitation in performing all physical activities including bathing or dressing, to 100 , indicating no limitation in performing all types of physical activities including the most vigorous.

An exposure was included if it had been shown in other studies to predict cardiovascular, respiratory or musculoskeletal disorders. Data on age, sex, employment grade, and menopausal status (women only), were obtained by questionnaire at follow up. Data on cigarette smoking, alcohol intake, physical activity, and eating habits were obtained by questionnaire at baseline. Employment grade within the civil service was used as a measure of socioeconomic status. Details are reported elsewhere. ${ }^{22}$ Three categories of physical activity were created: 
Table 2 Associations between health related behaviours, biochemical risk factors, and physical functioning. Results for all men and excluding those with physical diseaset, adjusted for age, employment grade, and all factors listed in table 2: Whitehall II study 1985-1993

\begin{tabular}{|c|c|c|c|}
\hline Potential correlate & Level & $\begin{array}{l}\text { All subjects Odds ratio } \\
(95 \% \mathrm{CI})\end{array}$ & $\begin{array}{l}\text { Excluding diseaset Odds } \\
\text { ratio }(95 \% \mathrm{CI})\end{array}$ \\
\hline $\begin{array}{l}\text { Health related behaviours } \\
\text { Cigarette smoking }\end{array}$ & $\begin{array}{l}\text { Never smoker } \\
\text { Ex-smoker } \\
\text { Current smoker } \leqslant 20 \text { packyears } \\
\text { Current smoker }>20 \text { packyears }\end{array}$ & $\begin{array}{l}1.00 \\
1.23(1.00,1.51) \\
1.18(0.80,1.74) \\
1.89(1.35,2.67) \\
\star \star\end{array}$ & $\begin{array}{l}1.00 \\
1.32(0.93,1.87) \\
1.40(0.74,2.66) \\
2.47(1.35,4.52) \\
\star \star\end{array}$ \\
\hline Alcohol intake & $\begin{array}{l}\text { Non-drinker } \\
\text { Moderate drinker ( } \leqslant 21 \text { units) } \\
\text { Heavy drinker ( }>21 \text { units) }\end{array}$ & $\begin{array}{l}0.95(0.49,1.87) \\
1.00 \\
1.16(0.93,1.45)\end{array}$ & $\begin{array}{l}1.11(0.37,3.35) \\
1.00 \\
1.22(0.84,1.78)\end{array}$ \\
\hline Physical activity & $\begin{array}{l}\text { Vigorous } \\
\text { Moderate } \\
\text { None/mild }\end{array}$ & $\begin{array}{l}1.00 \\
1.50(1.17,1.91) \\
1.63(1.25,2.13) \\
\star \star \star\end{array}$ & $\begin{array}{l}1.00 \\
1.48(0.97,2.26) \\
2.06(1.32,3.21) \\
\star \star\end{array}$ \\
\hline Eating habits & $\begin{array}{l}\text { Healthy diet } \\
\text { Average diet } \\
\text { Unhealthy diet }\end{array}$ & $\begin{array}{l}1.00 \\
1.09(0.85,1.41) \\
1.13(0.82,1.55)\end{array}$ & $\begin{array}{l}1.00 \\
0.85(0.56,1.29) \\
1.18(0.71,1.96)\end{array}$ \\
\hline $\mathrm{BMI}\left(\mathrm{kg} / \mathrm{m}^{2}\right)$ & $\begin{array}{l}<20 \\
20-24.9 \\
25-29.9 \\
\geqslant 30\end{array}$ & $\begin{array}{l}1.46(0.91,2.36) \\
1.00 \\
1.17(0.95,1.44) \\
1.71(1.13,2.59)\end{array}$ & $\begin{array}{l}1.25(0.58,2.68) \\
1.00 \\
1.05(0.74,1.49) \\
2.29(0.95,5.52) \\
\star\end{array}$ \\
\hline Cholesterol & $\begin{array}{l}\text { Lower tertile } \\
\text { Middle tertile } \\
\text { Upper tertile }\end{array}$ & $\begin{array}{l}1.00 \\
0.73(0.57,0.93) \\
0.95(0.75,1.21)\end{array}$ & $\begin{array}{l}1.00 \\
0.69(0.46,1.04) \\
0.89(0.60,1.33)\end{array}$ \\
\hline Triglycerides & $\begin{array}{l}\text { Lower tertile } \\
\text { Middle tertile } \\
\text { Upper tertile }\end{array}$ & $\begin{array}{l}1.00 \\
1.47(1.15,1.89) \\
1.68(1.29,2.19) \\
\star \star\end{array}$ & $\begin{array}{l}1.00 \\
1.88(1.25,2.83) \\
2.14(1.37,3.34) \\
\star\end{array}$ \\
\hline Fibrinogen & $\begin{array}{l}\text { Lower tertile } \\
\text { Middle tertile } \\
\text { Upper tertile }\end{array}$ & $\begin{array}{l}1.00 \\
1.01(0.80,1.29) \\
1.27(1.01,1.61) \\
\star \star \star\end{array}$ & $\begin{array}{l}1.00 \\
1.12(0.75,1.67) \\
1.32(0.89,1.97)\end{array}$ \\
\hline Glucose tolerance & $\begin{array}{l}\text { Normal } \\
\text { Impaired } \\
\text { Diabetic }\end{array}$ & $\begin{array}{l}1.00 \\
0.92(0.72,1.18) \\
1.32(0.68,2.53)\end{array}$ & $\begin{array}{l}1.00 \\
0.67(0.35,1.26) \\
\text { excluded }\end{array}$ \\
\hline Insulin & $\begin{array}{l}\text { Lower tertile } \\
\text { Middle tertile } \\
\text { Upper tertile }\end{array}$ & $\begin{array}{l}1.00 \\
0.92(0.72,1.18) \\
1.26(0.98,1.62)\end{array}$ & $\begin{array}{l}1.00 \\
0.99(0.67,1.47) \\
1.18(0.77,1.79)\end{array}$ \\
\hline $\begin{array}{l}\text { Physiological variables } \\
\text { Heart rate (beats per minute) } \ddagger\end{array}$ & $\begin{array}{l}<60 \\
60-69 \\
70-79 \\
\geqslant 80\end{array}$ & $\begin{array}{l}\star \star \star \\
1.00 \\
1.23(0.99,1.53) \\
0.88(0.66,1.16) \\
0.92(0.64,1.32)\end{array}$ & $\begin{array}{l}1.00 \\
1.16(0.81,1.65) \\
0.86(0.53,1.40) \\
1.84(0.98,3.47)\end{array}$ \\
\hline
\end{tabular}

Test for linear trend: ${ }^{\star \star \star} \mathrm{p}<0.001,{ }^{\star \star} \mathrm{p}<0.01,{ }^{\star} \mathrm{p}<0.05$. +Subjects with angina, possible or probable ischaemia on resting ECG, hypertension (blood pressure $>160 / 90$ or on antihypertensive medication, claudication, diabetes (self reported or oral glucose tolerance test), chronic bronchitis, musculoskeletal disorders or cancer at baseline or follow up were excluded. $\ddagger$ Adjusted for use of $\beta$ blockers.

"Vigorous" (subjects who reported at least 1.5 hours of vigorous activity per week), "Moderate" (subjects who reported at least 1.5 hours moderate activity but less than 1.5 hours vigorous activity per week), and "None/mild" (subjects who reported less than 1.5 hours either vigorous or moderate activity per week). Eating habits were coded from 0 (unhealthy diet) to 3 (healthy diet). A healthy diet consisted of wholemeal, granary or wheatmeal bread, skimmed or semi-skimmed milk, and fresh fruits or vegetables at least once daily. An unhealthy diet consisted of other types of bread and milk and less frequent consumption of fresh fruit and vegetables. Blood cholesterol, systolic and diastolic blood pressure, and body mass index (BMI, defined as weight $(\mathrm{kg})$ divided by height squared $\left(\mathrm{m}^{2}\right)$ ), were obtained at baseline screening. Triglycerides, fibrinogen, serum glucose, and insulin (taken two hours after an oral glucose tolerance test), and heart rate values obtained at follow up were used, as these measurements were either not available, or only available for a subsample of participants at baseline screening.
The following diseases, related to limitations in physical functioning, ${ }^{28}$ were identified at baseline and follow up (numbers in parentheses show number of subjects with disease): angina $^{29}(n=450)$, possible or probable ischaemia on resting ECG (Minnesota codes 1-1 to $1-3,4-1$ to $4-4,5-1$ to $5-3$ and $7-1-1$ $(\mathrm{n}=707)$ ), hypertension (blood pressure > $160 / 90$ or on anti-hypertensive medication $(\mathrm{n}=1554)$ ), claudication ${ }^{29}$ (reported at baseline only) $(n=125)$, diabetes (self report or oral glucose tolerance test $\left.^{30} \quad(\mathrm{n}=222)\right)$, chronic bronchitis $^{31}(\mathrm{n}=914)$, musculoskeletal disorders (self report $(n=1257)$ ), and cancer (registration or self report $(n=128)$ ). A total of 2716 men and 1206 women had one or more of the above diseases at baseline or follow up.

\section{ANALYSIS}

The distribution of physical functioning scores was skewed to the left and a large proportion of subjects attained the maximum possible score. To overcome the distributional problems caused by this ceiling effect, subjects were categorised according to whether or not they had poor 
Table 3 Associations between health related behaviours, biochemical risk factors, and physical functioning. Results for all women and excluding those with physical diseaset, adjusted for age, employment grade, menopausal status, and all factors listed in table 3 . Whitehall II study 1985-1993

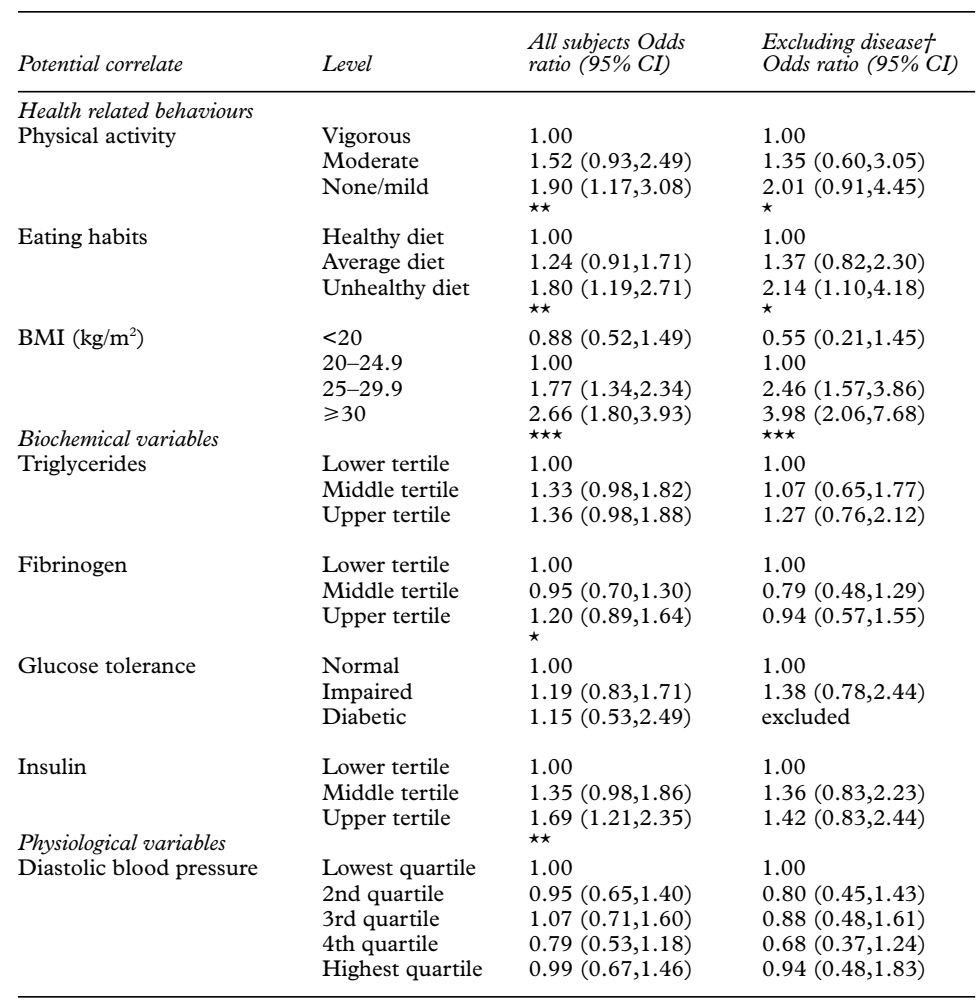

Test for linear trend: ${ }^{\star \star \star} \mathrm{p}<0.001,{ }^{\star \star} \mathrm{p}<0.01,{ }^{\star} \mathrm{p}<0.05$. + Subjects with angina, possible or probable ischaemia on resting ECG, hypertension (blood pressure $>160 / 90$ or on antihypertensive medication) claudication, diabetes (self reported or oral glucose tolerance test), chronic bronchitis, musculoskeletal disorders or cancer at baseline or follow up were excluded.

physical functioning (defined as a score in the lowest sex specific quartile). Using logistic regression, we examined the relations between physical functioning and each of the potential correlates separately, adjusting for age. We then included correlates identified above (where associations with physical functioning were significant at the $5 \%$ level), in one model and adjusted for age, employment grade, and menopausal status (women only). Associations between physical functioning and age and employment grade have been reported previously. ${ }^{32}$ Finally, subjects who reported physical disease at either baseline or follow up were excluded from the full model to determine whether associations with physical functioning were partially independent of physical disease.

All analyses were performed using the statistical package SAS (SAS, Cary, USA). Two tailed tests were used throughout. Odds ratios were calculated relative to a baseline group but tests for trend were performed on continuous variables.

\section{Results}

The median age (range) of participants at follow up was 49 years (39-63) for men and 50 years (39-63) for women. Median physical functioning score in the lowest quartile was 80 (ranging from 0 to 89 ) for men and 60 (0 to 75$)$ for women compared with a median of 95 (90 to 100) for men and 95 (80 to 100) for women not in the lowest quartile. Subjects who were in the lowest quartile of physical functioning reported that their ability to perform vigorous activities and to climb several flights of stairs was limited a lot. Their ability to perform moderate activities, lift and carry, bend and kneel, and walk more than one mile was limited a little.

Previous analyses showed that poor physical functioning was associated with older age and lower socioeconomic status. ${ }^{32}$ Table 1 shows the age adjusted associations between potential correlates and physical functioning. Physical functioning was related to smoking among men but not women, with never smokers being the least likely and current smokers who had smoked more than 20 pack years being the most likely to have poor physical functioning. The odds ratio of poor physical functioning was lowest for men who did not drink any alcohol and highest for heavy drinkers whereas women who did not drink any alcohol were more likely to have poor physical functioning than either moderate or heavy drinkers. Poor physical functioning was associated with less physical activity, less healthy eating habits, and increased BMI, although men with a BMI $<20$ $\mathrm{kg} / \mathrm{m}^{2}$ were more likely to have poor physical functioning than men with a BMI 20-24.9 $\mathrm{kg} / \mathrm{m}^{2}$. Men in the upper sex specific tertile of cholesterol were more likely to have poor physical functioning. The odds ratio of poor physical functioning was higher for subjects with high triglyceride, fibrinogen, serum glucose, and insulin levels for both men and women. Diastolic blood pressure was positively associated with physical functioning among women only, as was systolic blood (data not shown). Men with a heart rate of more than 60 beats per minute were more likely to have poor physical functioning than men with a heart rate of less than 60 beats per minute.

Tables 2 and 3 show the multivariate associations between correlates identified above (where significance reached the 5\% level), and physical functioning for men and women respectively. The first column shows results for all subjects and the second shows associations excluding subjects with disease at baseline or follow up, or both. For all men, independent effects of cigarette smoking, physical activity, BMI, triglycerides, fibrinogen, and insulin remained. Taking never smokers as the reference group, the odds ratio of poor physical functioning for men smoking > 20 pack years was $1.89(95 \%$ confidence intervals $1.35,2.67)$. The odds ratio of poor physical functioning for men with BMI $\geqslant 30 \mathrm{~kg} / \mathrm{m}^{2}$ was 1.71 (95\% CI 1.13, 2.59) compared with men with BMI $<20 \mathrm{~kg} / \mathrm{m}^{2}$. On exclusion of subjects with disease, the directions of these relations were unchanged although the associations between fibrinogen and insulin and physical functioning did not reach statistical significance. For some correlates, the effects got larger, although the power to detect a trend decreased because of smaller numbers. For all women, physical activity, eating habits, BMI, fibrinogen, and insulin were independently associated with physical functioning. Taking women with $\mathrm{BMI}<20 \mathrm{~kg} / \mathrm{m}^{2}$ as the reference group, the odds ratio of poor physical functioning for women with $\mathrm{BMI} \geqslant 30 \mathrm{~kg} / \mathrm{m}^{2}$ was 2.66 
(95\% CI 1.80, 3.93). On exclusion of subjects with disease, the results were essentially unchanged but again the effects of fibrinogen and insulin failed to reach statistical significance.

\section{Discussion}

We have shown that established risk factors for disease are also associated with poor physical functioning in this middle aged, high functioning cohort. For men, older age, lower employment grade, ${ }^{32}$ cigarette smoking, less physical activity, higher body mass index, higher triglycerides, higher fibrinogen, and higher insulin were independently associated with poor physical functioning. For women, older age, lower employment grade, ${ }^{32}$ less physical activity, less healthy eating habits, higher body mass index, higher fibrinogen, and higher insulin were independently associated with poor physical functioning, adjusting for menopausal status. With the exceptions of fibrinogen and insulin, these relations remained on exclusion of subjects with disease.

While other studies have measured more serious disability in elderly populations, ${ }^{3}{ }^{10-18}$ the results presented in this occupational cohort suggest that similar factors predict milder impairments in physical functioning in a younger population. This is consistent with the hypothesis that risk factors operate throughout the life course and may exert cumulative effects. These results should therefore be considered when investigating the timing and nature of strategies to prevent physical disability.

Theoretical models by which risk factors may be associated with physical functioning have been proposed. ${ }^{33}$ Associations may involve one or a combination of the following: (1) symptomatic disease, ${ }^{34}$ (2) pre-clinical disease $^{8}$ or (3) independently of disease, via anatomical or physiological impairment. As physical functioning may be influenced by both the number and severity of medical conditions, we anticipated that behavioural and biological effects would be weakened when subjects with disease were excluded. Our results did not support this; in fact, many of the effects were magnified on exclusion of subjects with disease. Independently of disease, physical functioning may be affected by smoking (via reduced lung function ${ }^{35}$ ), by excess body weight (because of increased wear and tear on joints, loss of flexibility, and limited cardiopulmonary capacity $^{36}$ ) and by lack of regular physical activity (via reduced cardiorespiratory functioning ${ }^{37}$ ). The correlation between physical functioning and physical activity was not large (coefficient $=0.28$ ) and there was considerable variation in physical functioning within each category of physical activity, indicating that physical activity is not just a proxy measure for physical functioning.

We considered the possibility that impaired physical functioning largely reflects exercise capacity, which itself is limited by the breathlessness associated with smoking and obesity. However, the lack of association between smoking and physical functioning in women suggests that breathlessness is not the sole

\section{KEY POINTS}

- Risk factors for poor physical functioning in young, non-patient populations have not previously been identified.

- The prevalence of physical disability is increasing and has cost implications for the health and social services.

- For men, cigarette smoking, physical activity, triglycerides, fibrinogen, insulin, and body mass index predicted poor physical functioning.

- For women, the risk factors identified were physical activity, healthy eating, fibrinogen, insulin, and body mass index.

- Changes in health related behaviour may lower the risk of poor physical functioning.

determinant of impaired physical functioning. Additionally, associations were seen in the subgroup of subjects who had never smoked and those who had BMI $<27 \mathrm{~kg} / \mathrm{m}^{2}$. This indicates that residual confounding by smoking and obesity causing breathlessness did not explain the relations seen between the other risk factors identified and physical functioning.

Certain limitations of the study should be noted. As the outcome was measured only at follow up, it is possible that subjects had poor physical functioning at baseline or before and that this may have influenced their baseline risk factors. Although this possibility cannot be ruled out, the consistency of associations with physical functioning across behavioural and biological risk factors and the fact that these associations remained when subjects with physical disease (and poorer physical functioning), were excluded suggest that unhealthy behaviour may precede poor physical functioning. Another limitation is the possibility of reporting bias, as both health related behaviours and physical functioning were self reported. However, there is evidence that subjective and objective physical functioning are highly correlated. ${ }^{38}$ Furthermore, biological measures are not subject to reporting bias and these showed similar associations with physical functioning. (Although these measures were taken at the same time as measurement of physical functioning, the same bivariate associations were found using baseline biochemical data available for a sub-sample of subjects.) Bias caused by non-response at follow up was probably conservative, as subjects who were not included in the analysis because of missing data tended to have unhealthy lifestyles, higher biochemical risk factors, and poorer physical functioning.

It is possible that the associations between health related behaviours and physical functioning are confounded by poor mental health. Poor psychological well being is associated with smoking, lack of exercise, and an unhealthy diet ${ }^{39} 40$ as well as with poor physical functioning. ${ }^{41-43}$ An unhealthy lifestyle may therefore lead to poor physical functioning resulting from lower expectations of ability and poor self esteem. ${ }^{44}$ However, on adjustment for psychological well being, measured 
by the general mental health scale of the SF-36, the associations between risk factors and physical functioning remained, although weakened slightly. It is unlikely therefore that confounding by poor mental health can fully explain the observed relations.

Previous work has shown that socioeconomic status is associated with risk factors and physical functioning. ${ }^{12} 13222332$ Future analyses in the Whitehall II study will investigate possible mediating pathways between socioeconomic status and physical functioning by examining the relative contribution of psychosocial, behavioural and biological factors. These analyses will also consider the question of whether, like other measures of self reported health, the physical functioning scale of the SF-36 predicts use of health services and mortality.

We have demonstrated associations between health related behaviours (smoking, physical activity, diet, and obesity), biological factors (triglycerides, fibrinogen, and insulin), and poor physical functioning in a comparatively young, high functioning population. Our findings are consistent with the hypothesis that sub-clinical disease or cardiorespiratory fitness have effects on physical functioning. As well as the potential for preventing future disease, changes in health related behaviour may prevent more immediate limitations in physical functioning.

Funding: the study was supported by grants from the Agency for Health Care Policy and Research (5 RO1 HS06516), the New England Medical Centre-Division of Health Improvement, the National Heart Lung and Blood Institute (2RO1 HL36310), the John D and Catherine T MacArthur Foundation Research Network on Successful Midlife Development, the Institute for Work and Health, Ontario, Canada, the Volvo Research Foundation, Sweden, Medical Research Council, Health and Safety Executive, and the British Heart Foundation. MM is supported by a Medical Research Council Professorship.

We thank all participating civil service departments and their welfare, personnel and establishment officers; the Civil Service Occupational Health Service: Dr George Sorrie, Dr Adrian Semmence and Dr Elizabeth McCloy; the Civil Service Centra Monitoring Service and Dr Frank O'Hara and the Council of Civil Service Unions.

Conflicts of interest: none

1 Ware JE. The status of health assessment 1994. Annu Rev Public Health 1995;16:327-54.

2 Greenfield S, Nelson EC. Recent developments and future issues in the use of health status assessment measures in clinical settings. Med Care 1992;30 (suppl 5):23-41.

3 Harris T, Kovar M, Suzman R, et al. Longitudinal study of physical ability in the oldest-old. Am f Public Health 1989; 79:698-702.

4 Marmot MG, Feeney A, Shipley M, et al. Sickness absence as a measure of health status and functioning: from the UK Whitehall II Study. 7 Epidemiol Community Health 1995;49: 124-30.

5 Kaplan GA, Camacho T. Perceived health and mortality: a nine-year follow-up of the human population laboratory nine-year follow-up of the human population
cohort. Am f Epidemiol 1983;117:292-304.

6 Mossey J, Shapiro E. Self rated health: a predictor of mortality among the elderly. Am F Public Health 1982;72:800-8.

7 Idler EL, Angel RJ. Self-rated health and mortality in the NHANES-I epidemiologic follow-up study. Am f Public NHANES-I epidemiolo

8 Bild DE, Fitzpatrick A, Fried LP, et al. Age-related trends in cardiovascular morbidity and physical functioning in the elderly: the Cardiovascular Health Study. I Am Geriatr So 1993;41:1047-56.

9 Kaplan G. Epidemiologic observations on the compression of morbidity: evidence from the Alameda county study. $f$ Aging Health 1991;3:155-71.

10 Pinsky JL, Branch LG, Jette AM, et al. Framingham disability study: relationship of disability to cardiovascular risk factors among persons free of diagnosed cardiovascular disease. Am $\mathcal{F}$ Epidemiol 1985;122:644-56.

11 Pinsky J, Leaverton P, Stokes JI. Predictors of good function: the Framingham study. $f$ Chronic Dis $1987 ; 40$ (suppl 1):159-67.

12 Strawbridge WJ, Camacho TC, Cohen RD, et al. Gender differences in factors associated with change in physical
functioning in old age: a 6 year longitudinal study. Gerontologist 1993;33:603-9.
13 Palmore EB. Predictors of function among the old. 7 Gerontol 1985;40:244-50.

14 Markides KS, Lee DJ. Predictors of well-being and functioning in older Mexican Americans and Anglos: an eight-year follow-up. Gerontology 1990;45:S69-73.

15 Berkman LF, Seeman T, Albert M, et al. High, usual and impaired functioning in community dwelling older men and women: findings from the MacArthur Foundation research network on successful aging. $\mathcal{F}$ Clin Epidemiol 1993;46:1129-40.

16 Seeman TE, Charpentier P, Berkman L, et al. Predicting changes in physical performance in a high functioning elderly cohort: MacArthur Studies on Successful Aging. 7 Gerontol 1994;49:M97-108.

17 Ettinger WH, Davis MA, Neuhaus JM, et al. Long-term physical functioning in persons with knee osteoarthritis rom NHANES 1: effects of comorbid medical conditions. f Clin Epidemiol 1994;47:809-15.

18 Branch LG. Health practices and incident disability among the elderly. Am F Public Health 1985;75:1436-9.

19 Guadagnoli E, Hauptman P, Ayanian J, et al. Variation in the use of cardiac procedures after acute myocardial infarction. N Engl F Med 1995;333:589-90.

20 Garratt AM, Ruta D, Abdall M, et al. The SF-36 health survey questionnaire:an outcome measure suitable for routine use within the NHS? BMF 1993;306:1440-4

21 Lyons RA, Lo SV, Littlepage BNC. Comparative health status of patients with 11 common illnesses in Wales. $\mathcal{F}$ Epidemiol Community Health 1994;48:388-90.

22 Marmot MG, Davey Smith G, Stansfeld S, et al. Health inequalities among British Civil Servants: the Whitehall II study. Lancet 1991;337:1387-93.

23 Brunner EJ, Marmot MG, White IR, et al. Gender and employment grade differences in blood cholesterol, apolipoproteins and haemostatic factors in the Whitehall II poproteins and haemostatic factors in

24 Ware JE, Sherbourne CD. The MOS 36 -item short-form health survey (SF-36):I. Conceptual framework and item selection. Med Care 1992;30:473-83.

25 McHorney CA, Ware JE, Raczek AE. The MOS 36-item short-form health survey (SF-36): II. Psychometric and clinical tests of validity in measuring physical and mental health constructs. Med Care 1993;31:247-63.

26 McHorney CA, Ware JE, Lu JFR, et al. The MOS 36-item short-form health survey (SF-36): III. Test of data quality, scaling assumptions, and reliability across diverse patient groups. Med Care 1994;32:40-66.

27 Ware JE, Snow KK, Kosinski M, et al. SF-36 Health survey manual and interpretation guide. Boston: New England Medical Center, 1993

28 Ettinger WH, Fried LP, Harris T, et al. Self-reported causes of physical disability in older people: the Cardiovascular Health Study. F Am Geriatr Soc 1994;42:1035-44.

29 Rose G, Blackburn H, Gillum RF, et al. Cardiovascular survey methods. Geneva: World Health Organization, 1982. 30 WHO. Study Group Diabetes mellitus. Report of a WHO Study Group, Geneva: World Health Organization, 1985.

31 Medical Research Council. Questionnaire on respiratory symptoms and instruction for interviewers. London: MRC, 1976.

32 Hemingway H, Nicholson A, Stafford M. The impact of socioeconomic status on health functioning as assessed by the SF-36: the Whitehall II study. Am f Public Health 1997; 87:1484-90.

33 Nagi SZ. An epidemiology of disability among adults in the United States. Milbank Mem Fund Q Health Soc 1976;54: 439-67.

34 Bowling A. The effects of illness on quality of life: findings from a survey of households in Great Britain. 7 Epidemiol Community Health 1996;50:149-55.

35 Sandvik L, Erikssen G, Thaulow E. Long term effects of smoking on physical fitness and lung function: a longitudinal study of 1393 middle aged Norwegian men for seven years. BMF 1995;311:715-18.

36 Rubinstein I, Zamel N, DuBarry L, et al. Airflow limitation in morbidly obese, nonsmoking men. Ann Intern Med 1990;112:828-32.

37 Morris JN. Exercise in the prevention of coronary heart disease: today's best buy in public health. Med Sci Sport Exerc 1994;26:807-14

38 Yates BC, Belknap DC. Predictors of physical functioning after a cardiac event. Heart Lung 1991;20:383-90.

39 Stewart AL, Hays RD, Wells KB, et al. Long-term functioning and well-being outcomes associated with physical activity and exercise in patients with chronic conditions in the medical outcomes study. F Clin Epidemiol 1994;47:719-30.

40 Mackenbach JP, van-des Bos J, Joung IM, et al. The determinants of excellent health: different from the determinants of ill-health? Int $\mathcal{F}$ Epidemiol 1994;23:127381 .

41 Spitzer RL, Kroneke K, Linzer M, et al. Health-related quality of life in primary care patients with mental disorders. FAMA 1995;274:1511-17.

42 Spiegel JS, Leake B, Spiegel TM, et al. What are we measuring? An examination of self-reported functional status measures. Arthritis Rheum 1988;31:721-8.

43 Satin MS, Monetti CH. Census tract predictors of physical, psychological, and social functioning for needs assessment. Health Serv Res 1985;20:341.

44 Rovario S, Holmes DS, Holmsten RD. Influence of a cardiac rehabilitation program on the cardio-vascular, psyhchological, and social functioningof cardiac patients. $\mathcal{F}$ Behav Med 1984;7:61-81. 